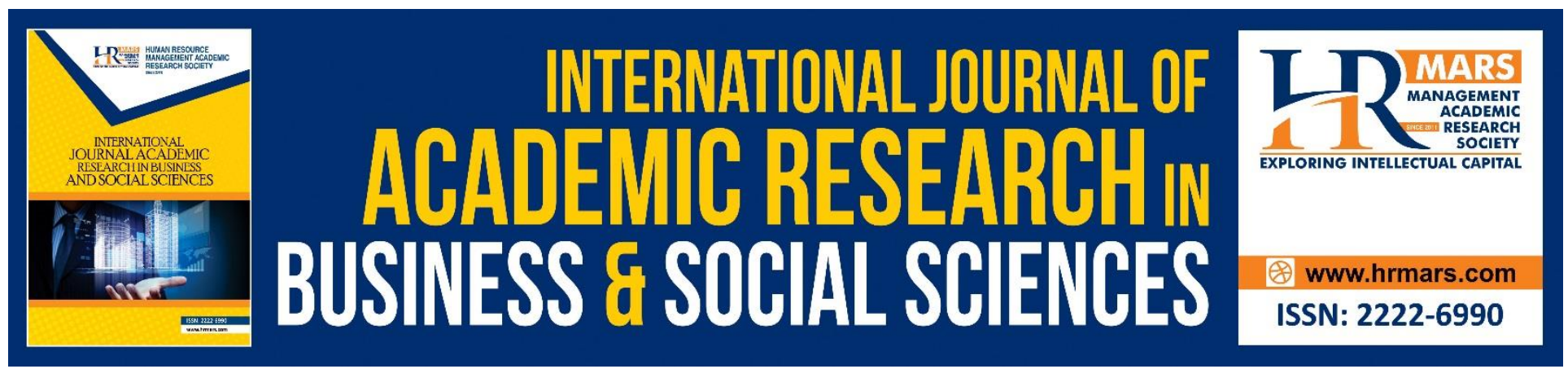

\title{
How to Achieve the Indonesian Society Happiness in Islamic Way?
}

Dwi Sri Dani Afriza, Muhammad Zilal Hamzah

To Link this Article: http://dx.doi.org/10.6007/IJARBSS/v8-i11/4957

DOI: 10.6007/IJARBSS/v8-i11/4957

Received: 21 Oct 2018, Revised: 16 Nov 2018, Accepted: 30 Nov 2018

Published Online: 11 Dec 2018

In-Text Citation: (Afriza \& Hamzah, 2018)

To Cite this Article: Afriza, D. S. D., \& Hamzah, M. Z. (2018). How to Achieve the Indonesian Society Happiness in Islamic Way? International Journal of Academic Research in Business and Social Sciences, 8(11), 812-825.

Copyright: (C) 2018 The Author(s)

Published by Human Resource Management Academic Research Society (www.hrmars.com)

This article is published under the Creative Commons Attribution (CC BY 4.0) license. Anyone may reproduce, distribute, translate and create derivative works of this article (for both commercial and non-commercial purposes), subject to full attribution to the original publication and authors. The full terms of this license may be seen

at: http://creativecommons.org/licences/by/4.0/legalcode

Vol. 8, No. 11, 2018, Pg. 812 - 825

http://hrmars.com/index.php/pages/detail/IJARBSS

JOURNAL HOMEPAGE

Full Terms \& Conditions of access and use can be found at http://hrmars.com/index.php/pages/detail/publication-ethics 


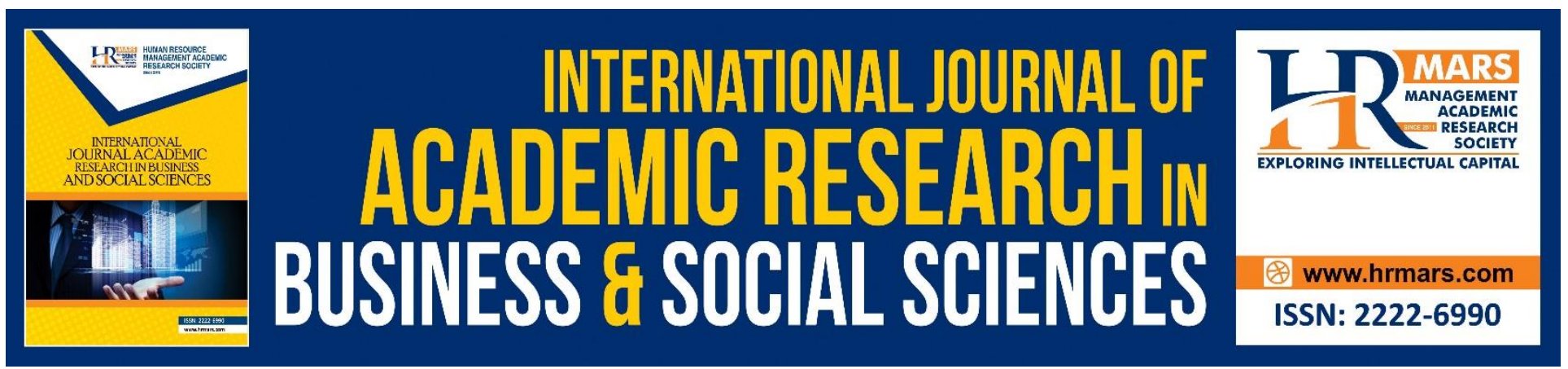

\title{
How to Achieve the Indonesian Society Happiness in Islamic Way?
}

\author{
Dwi Sri Dani Afriza \\ Universitas Trisakti, Doctoral Program of Islamic Economic and Finance, Economic Faculty and \\ Business, Jakarta, Indonesia \\ Muhammad Zilal Hamzah \\ Sekolah Tinggi Ilmu Ekonomi Bisnis Indonesia, Jakarta, Indonesia
}

\begin{abstract}
This study aims to examine the effect of macroeconomic factors: gross domestic product, inflation, money circulation, population, poverty, human development index (HDI), labor force, productivity, and labor costs toward the achievement of Indonesian people's happiness index in Islamic perspective. It is believed that the achievement of community happiness is closely related to the success of economic development by a country. The design of this research is descriptive research design with quantitative approach to generate in-depth information from secondary data (period 2004-2014) that obtained from Bank Indonesia, Central Bureau of Statistics (BPS), International Financial Statistic (IFS), CIA FACT Book. Time period is selected to be observed with the latest range of time range. Processing and analysis of this research is done by using E-views software. The result of the research indicates that the macroeconomic variables before the applied of sharia compliance have not influenced overall toward index of happiness of Indonesian society. However, by given the value of sharia compliance (tetha) to each variable, the results show that almost of macroeconomic variables have significant effects on the index of happiness of Indonesian society.
\end{abstract}

\section{INTRODUCTION}

Economics development is an important part of national development in Indonesia. One of economics development those propose of this country is to improve the standard of living and quality of life (Subandi, 2011). Economics development is also a process to increase the real per capita income of a country. The increase on per capita income will have an impact for the betterment of society, such as through an increase in education and health. Economics development also defined as a series of efforts in the economy to develop its economics so that more infrastructures will be available, more companies will emerge and more growing, higher level of education and increase in technology and will increase the prosperity of the community (see among others: Rumbia, 2009). 
INTERNATIONAL JOURNAL OF ACADEMIC RESEARCH IN BUSINESS AND SOCIAL SCIENCES Vol. 8, No. 11, Nov, 2018, E-ISSN: 2222-6990 @ 2018 HRMARS

Furthermore Todaro et al. (2004) says that economics success of a certain country be evidenced by three basic values: first, development of social capability to meet their basic needs like raising availability and enlargement of distribution of various goods of basic living needs like food, clothing, housing, health and security protection; second, enhancement of society self esteem as human being through enhancement of living standard such as like the increase of income, covering the addition of availability of job opportunity, improvement of quality of education and also to enhance the interest for cultural and humanitarian values; and third, social capability improvement in freedom of slavery by enlarging economic and social alternatives for every individual and generally for the nation.

Development strategy with resting on growth without considering the potential of population and the condition of existing natural resources and environment will not been proceed in a sustained manner. Salim (2010) states that although conventional development has been able to raise economic growth, but failed in the social and environmental aspects. This is because conventional development has placed social and environmental factors at a less important position. So that in entering the $21^{\text {st }}$ century, conventional development model can no longer be accepted, because it has caused greater imbalance in income distribution between countries and within a country (see also: Chapra, 2008 and Choudury, 2004).

Income, money and prices are important macro variables which play crucial role in an economy (Mankiw, 2006). A clear understanding, or at least insight, on the relationship between these macroeconomic variables are of significant importance, particularly to policymakers in ensuring that effective macro-economic stabilization policies can be designed and implemented. Monetary policymakers use the various tools they have to meet social objectives. Their goals are to keep inflation low and stable and to attain high economic growth in the real economy. The primary purpose of all Islamic teaching is to blessing for mankind. One of the indispensible ways to realize this goal is to promote the falah or real well-being of all human beings on earth through real economics activities. The falah also includes price stability, which constitutes a pivotal framework condition for economic activity, and stable growth.

The notion of happiness in the Islamic perspective is that in his life, man always seeks happiness (As-sa'adah) and so on instinctively seeks the total happiness, the highest good, which in ethical science is called (Al-Khair al-Kulliy). No human being, while still in good health, wants to be wretched or destitute or fails in his life. Every human being even has a goal he wants to achieve. In fact, people living this life are always faced with good pleasures and bad bitterness. When it comes to goodness or pleasure in life, people feel that there is no problem in living their life, but when it comes to difficulties then it's just about complaining, one of them is a disaster.

Happiness is a feeling that is in the heart. It is characterized by peace of mind, happiness, and a tendency to relax. It comes as a result of proper behavior, both inward and outward and inspired by strong faith. The Messenger of Allah (SAW) said, "True enrichment does not come through having much wealth, but right enrichment is the enrichment of the soul". This is the trait that is needed for every person who wants to seek happiness. One of the most difficult to understand from every human being is 'happiness'. The Qur'an reveals the secret to achieving the perfect bliss in this life and forever. We learn from the Qur'an that happiness is the exclusive quality of the soul. Thus, the body achieves all the material successes for money, power, fame and others, but that all may not 
INTERNATIONAL JOURNAL OF ACADEMIC RESEARCH IN BUSINESS AND SOCIAL SCIENCES

Vol. 8, No. 11, Nov, 2018, E-ISSN: 2222-6990 @ 2018 HRMARS

always belong to a happy person. From an Islamic point of view, happiness is not limited to material prosperity, though matter makes some elements of happiness. The material aspect is just a means, but not the purpose itself. The main focus in achieving happiness is on the worries of non-material factors. Happiness depends entirely on the level of growth and development achieved by the soul. The Qur'an provides a detailed route to the perfect bliss for the body and soul, both in this world and in the hereafter.

The rationale of this study in terms of the above mentioned learning characteristics is epistemological. The axiom is based solely on the basis of a known view of the world of knowledge which interconnects the mind (cognition) and matter (the world system). The worldview in question is the unity of the divine law and the application for "everything". This worldview in the Qur'an is called Tawheed (monotheism). After this epistemic rationale was initiated the dynamics of evolutionary learning from the probabilistic model of the field of learning. Finally, this paper tries to study the determinant factors that affect the happiness in Indonesia through Islamic Way.

\section{THEORETICAL BACKGROUND}

\section{A. Happiness (Hasanah) and Prosperity (Maslahah)}

In a life of happiness and well-being must be something beautiful and also seen by the person whose life is beautiful. But what is beautiful? Colette interpreted, endowed by the good fortune of Allah SWT. But many will say that a beautiful life must also be objectively and psychologically satisfactory, as well as psychologically satisfying most (but not entirely) by being objective and valuable. Of course, everyone does not share the same view of this. Perhaps according to some people, everything you need for well-being or happiness is a psychological fulfillment, or that is coupled with success in meeting your own set of standards. There is no objective standard of welfare or happiness, so your worthy life goals are irrelevant to your well-being. It seems there are many reasons to choose happiness because of choosing prosperity or developing to refer to good prudential life. The term "happiness" and "fulfillment of needs" or "sense of satisfaction" will be used for positive emotions, thoughts, and evaluations whether conscious, unconscious, or generally regarded as part of such a life.

Since most of us realize, that happiness is a very fine quality that includes satisfaction and peace; happiness is a gentle joy that causes lips, faces and hearts to smile. It is determined by faith in God and obedience to Him. So happiness creates peace and submission, peace in Islam. Islamic orders and regulations strengthen the happiness that comes from knowing God and they help ensure the happiness of humankind during life in this world. However, Islam also emphasizes that the life of the world is no more than the means to achieve the hereafter. By following the Islamic guidelines this allows people to be happy while waiting for our eternal happiness in life. From Anas RA, he said: The most frequent prayer of Rasulullah SAW is: O Allah, grant us kindness in the world and goodness in the Hereafter, and guard us from the punishment of the fire of hell.

So popular is the prayers contained in the Qur'an, the letter Al-Baqarah, Verse 201. In the pilgrimage, this prayer appears to be the idol of the pilgrims. When entering Masjidil Haram, the $K a$ 'bah was seen, the prayer was read: "Allohumma antassalam waminkassalam fahayyina robbana bissalam". Then walk towards Hajar Aswad to start the thawaf. When it's near Hajar Aswad, it might be a kiss or just gesture while reading: "Bismillah wallohu akbar". Next round the Ka'bah seven times, 
the Ka'bah position on the left. Starting from the corner of Hajar Aswad, walking towards the Iraqi pillar (this corner is in line with Iraq), then to Shami, then to the Yamani Rukun. Upon the foundation of Yamani, go to the Hajar Aswad Rukun. Between Yamani and Hajar Aswad read the world's prayer broom: "robbana atina fiddunya hasanatan wa fil akhira hasanatan waqina adzabannar". The Messenger of Allah (may peace be upon him) whenever each tawaf came between the Yamani and Hajar Aswad Rukun read the prayer

Ibn Abbas RA, a friend of Rasulullah SAW who is very careful in maintaining and serving the Prophet. One day he was asked by the Tabi'in (generation after the death of the Messenger of Allah) about what is meant by word happiness. He said that there are seven indicators of word happiness, namely (Sahih Al-Bukhari): (i). Qalbun syakirun or a heart that is always grateful; (ii). Al azwaju shalihah, that is the life partner who sholeh; (iii). Al auladun abrar, that is a righteous child; (iv). Albiatu sholihah, a conducive environment for our faith; (v). Al malul halal, or lawful property; (vi). Tafakuh fiddien, or spirit to understand religion; and (vii). Age of baroqah.

How can God be blessed with the seven indicators of the happiness of the world? In addition to our hard work to improve ourselves, then it is very good and there is no harm in diligence, frequent and khusyu 'beg to Allah SWT read the prayer "broom of the universe". Asking Allah SWT to the seven indicators of world happiness mentioned by Ibn Abbas RA above.

\section{B. Gross Domestic Product (GDP)}

GDP is commonly used as a measure of social welfare. GDP is designed as a measure of market output with the diverse output of the various goods and services produced during a given period aggregated into a single number using market valuation. GDP is often regarded as the best measure of the economy performance where GDP summarizing economic activity within a certain monetary value for a certain period. Total GDP as a proxy for income communities have a major influence for the banks, especially in raising funds. Effect of interest rates on savings rate is declined by Keynes (1937). Keynes argued that the higher level of income that ensures equality between saving and investment than interest rates. So only fitting that we receive revenues must be managed properly as stated in the Surah An Nisa (4:5); "To those weak of understanding make not over your property which Allah hath made means of support for you, but feed and clothes them therewith and speak to them words of kindness and justice".

Islam claims that it intends guiding mankind towards betterment in this world and hereafter by providing guidance in all spheres as it is a complete code of life (Al-Quran, 5:3). Islam not only encompasses the alpha and omega of worshiping one God (Allah), but it also distinguishes the right ways of all practical affairs in business, governance, economics growth, social justice, etc. All the rules set by Islam are the practical and golden laws which are beneficial for the community, and is pure from losses to an individual (Kayed and Hassan, 2010). Therefore, Islam and secularism are two opposite concepts. A religion is considered to be the only set of theology and theories meant for the spiritual reform and peace of mind for a human (Joseph, 2005). Routine life affairs in business, governance and politics, etc., are recommended to be segregated from religions by the seculars (Keysar and Kosmin, 2008; Poddar et al., 2008 and Irawan, 2009). However, Islam, that is the final Divine religion does not provide room for separating religion from routine life affairs. Unlike other 
INTERNATIONAL JOURNAL OF ACADEMIC RESEARCH IN BUSINESS AND SOCIAL SCIENCES

Vol. 8, No. 11, Nov, 2018, E-ISSN: 2222-6990 @ 2018 HRMARS

religions which are usually set of spiritual concepts, Islam guides mankind in all daily life matters as well.

\section{Inflation}

In economics, inflation is defined as a rise in the general level of prices of goods and services. Keynesians believe that inflation is a pricing phenomenon. They propose that inflation is the result of pressures in the economy; an increase in aggregate demand, a drop in aggregate supply, or a rise in labor cost. From the viewpoint of the Monetarists, inflation is regarded as erosion in the purchasing power of money. They assert that inflation has always been a monetary phenomenon. When the price level rises, each unit of currency buys fewer products.

In general, inflation rate is defined as the percentage rate of increase in price level. The price level is taken as the average price of a representative basket of goods consumed by all households in the nation. This must occur over a protracted period of time. Thus, inflation does not equate with price changes that are due to commodity substitutes and for temporary periods of tine due to shortrun scarcity. The symptoms of inflation are defined in relation to the cause of inflation. In general, Inflation refers to sustained percentage changes in the price level and the price increase must be in the general level of process. Fisher (1991) even suggests interpreting the rate of inflation as an indicator for the capability of a government to keep the fluctuations of its economy under control.

\section{Money Supply}

Economists define a country's money supply along a spectrum ranging from high to low liquidity: the ease with which an asset can be used as a generally acceptable means of payment, or at least converted into a means of payment. Various monies can range along a spectrum from coin and paper currency (cash), called M0 and M1, which is M0 plus checkable bank deposits; to M2, which is M1 plus savings and other similar short-term but non checkable deposits; to $M 3$, which includes longerterm deposits and so on. The precise definitions vary from country to country (Adam and Jane, 1995).

\section{E. Population}

Every country has a different amount of population. Eventhough, population also must be controlled because of the amount of population has the effect to economic growth of a country (see: Proud'homme, 1995; and Bahl and Lihn, 1994 in Hamzah, 2011). There are two views regarding the impact of population growth on economic growth. The pessimistic views see a rapid population growth as a burden to the economy since it would overwhelm any technological progress and capital accumulation. Contrary to this, the optimistic views believe that a rapid population growth allows a particular country to exploit economies of scale and promote technological progress.

The world's population is getting older because of longer life expectancy and lower fertility rates in most countries. These developments often interact - as countries become richer and healthier, their inhabitants live longer, but also give birth to fewer children. In poorer countries, children have traditionally been seen as investments, while in richer countries it is rather the case that they, at an individual level, require investment. Furthermore, in wealthier countries where women tend to have more career options, they also seem less willing to spend too much time away from the labor market taking care of children. Of course, policy and infrastructure also have their 
implications; in countries where women can return to work after childbearing without losing too much status and/or income, fertility is often higher. For example, in Norway and Sweden, two countries with long allowances for maternity leave, but also strong laws and regulations prohibiting discrimination against women and "parents", the fertility rates are higher than in Japan and Spain, countries where the costs of staying at home with children may be higher in terms of career. Population change is not an adverse factor for economic growth, for it has an endogenous effect emanating from household decisions corresponding to the extent of complimentary between the household production function and the national economy.

\section{F. Poverty}

Poverty is "pronounced deprivation in wellbeing". The conventional view links well being primarily to command over commodities, so the poor are those who do not have enough income or consumption to put them above some adequate minimum threshold. This view sees poverty largely in monetary terms. Poverty may also be tied to a specific type of consumption; for example, people could be house poor or food poor or health poor. These dimensions of poverty often can be measured directly, for instance, by measuring malnutrition or literacy. The broadest approach to wellbeing (and poverty) focuses on the capability of the individual to function in society. Poor people often lack key capabilities; they may have inadequate income or education, or be in poor health, or feel powerless, or lack political freedoms. The world has never been richer. At the same time, the number of people living in poverty has increased by almost 100 million and the chasm between the rich and the poor has become unfathomable (Antony and Laxmaijah, 2008).

\section{G. Human Development Index}

During the last few years, sustainable development has represented as one of the most important policy goals at global level. In the consideration of social dimension of sustainable development, HDI of the UNDP represent a widely accepted methodology to be used as starting point for building a more sustainable-oriented development index (Constantini and Monni, 2005). This point of view is also supported by Xiaoyan and Liming (2008) stating that HDI is the effective indicator to evaluate sustained development particular regional area. According to the UNDP (2011), definition of human development is a much wider paradigm of development than merely the increase or decrease of national income. Human development is one effort to create an environment where society may develop all its capabilities or potential to be directed towards Endeavour of a more productive and creative life in accordance with its need and attraction. Society is the genuine wealth of a country. Development is hereby related to widening choices for society towards a more beneficial life (http.undp.org/en/ humandev/2011).

\section{H. Labor Force}

The skill of the workforce is a dominant input of a manufacturing system. Caves and Barton (1990) observed that efficiency of transformation of inputs to outputs is largely dependent on the skill of the workforce. As stated by Cobb-Douglas, workforce skill is one of the main inputs of a production process. Furthermore, degree of skill is recognized as an effective driving force for enhancing manufacturing performance (Anwar and Watanabe, 2010 and Barro and Sala- I Martin, 2004). It is 
INTERNATIONAL JOURNAL OF ACADEMIC RESEARCH IN BUSINESS AND SOCIAL SCIENCES

Vol. 8, No. 11, Nov, 2018, E-ISSN: 2222-6990 C 2018 HRMARS

evident that the highly-productive manufacturing organizations tend to have a highly-educated and skilled workforce; more so than the least productive

\section{Productivity}

High productivity is generally assumed to be a "good thing" in so much as a productive operation is more likely to have lower costs. It is this close connection with the cost performance of an operation of process that accounts for the interest in understanding and measuring productivity (Slack, 1997).

\section{J. Labour Cost}

The concept of labour in Islam emanates from a concept of intrinsic value as the real worth of a produced thing as well as factor of production. We have taken the Quranic precept that says Allah has put fitrah in all things during creation and this assumes the primordial value of being in cognitive forms. Hence, if a good is discovered, produced and labour is expended in its production and transaction, there is always that primordial intrinsic value that has in the first place made all the subsequent processes possible. Wages, according to Islamic principles, should be determined prior to work and immediately paid after work is accomplished. The Prophet said: "Give the labour his wages before his sweat dries" (Ibn Majah). The Prophet also said: Allah says, "There are three people whom I shall be their opponent on the day of judgment:... (one of them is) A man who hires a labour, makes use of his service then does not give him his wages' (HR. Bukhari).

\section{METHODOLOGY}

This research design was descriptive research design with a quantitative approach in order to generate in-depth information from secondary data as obtained from the Central Bank of Indonesia, Central Statistical Bureau (BPS), International Financial Statistic (IFS), CIA FACT Book, etc. This research will be concentrated in the recent performance of Indonesian wellbeing between the periods of 2004 to 2014. The time period was selected considering that it offers recent time series observations. Mean while the model is:

$Y=\alpha+\beta_{1} X_{1}+\beta_{2} X_{2}+\beta_{3} X_{3}+\beta_{4} X_{4}+\beta_{5} X_{5}+\beta_{6} X_{6}+\beta_{7} X_{7}+\beta_{8} X_{8}+\beta_{9} X_{9}+e$

Where: $Y=$ Happiness Index; $X_{1}=$ GDP; $X_{2}=$ Inflation; $X_{3}=$ Money Market; $X_{4}=$ Population; $X_{5}=$ Poverty; $X_{6}=$ Human Development Index; $X_{7}=$ Labor; $X_{8}=$ Productivity; $X_{9}=$ Minimum Wage

\section{RESULTS}

A. Descriptive Statistics

Based on Table 1 below, can be explained the minimum, maximum, and mean values and the standard deviation value of each variable. The results of testing the classical assumption concluded that the regression model in this study is feasible to use because the regression model has been free from the problem of data normality (its Jarque-Bera value of $0.846064<60,48$ and the probability level of $0.655058>0.05$ ), no heteroscedastisity (the value of Prob. Obs * R-squared of $0.0763>$ alpha $0.05)$ and no autocorrelation. 
INTERNATIONAL JOURNAL OF ACADEMIC RESEARCH IN BUSINESS AND SOCIAL SCIENCES Vol. 8, No. 11, Nov, 2018, E-ISSN: 2222-6990 @ 2018 HRMARS

Table 1.

Descriptive Statistics

\begin{tabular}{|l|r|r|r|r|}
\hline & Minimum & Maximum & \multicolumn{1}{c|}{ Mean } & $\begin{array}{c}\text { Std. } \\
\text { Deviation }\end{array}$ \\
\hline GDP (Billion Rp) & $599.478,00$ & $2.72 .8846,0$ & $1.527 .432,4$ & $695.189,635$ \\
& 2,78 & 0 & 545 & 23 \\
Inflation (\%) & 17,11 & 7,4845 & 3,94917 \\
Money Supply & $1.033 .877,0$ & $5.115 .547,0$ & $2.437 .082,4$ & $1.241 .148,51$ \\
(Billion Rp) & 0 & 0 & 545 & 871 \\
Human Dev Index & 157.941 .16 & 182.597 .96 & & $15.592 .246,0$ \\
& 9,00 & 6,00 & 170.035 .371 & 7927 \\
Poverty (Million) & 27,73 & 39,30 & 32,8173 & 3,94617 \\
(\%) & 68,70 & 74,40 & 71,6755 & 1,75718 \\
Labor Force (Million) & 93,72 & 110,81 & 103,6736 & 6,93901 \\
Labor Cost & 458,50 & 1595,90 & 886,8364 & 352,99769 \\
(Thousand Rp) & 50,00 & 58,92 & 56,0182 & 2,73416 \\
Happiness Index & & & \\
\hline
\end{tabular}

Source: processed researchers

\section{B. Result of Regression Equation Model}

From table 2, below,

Table 2.

Estimated OLS Model Results

Dependent Variable: $Y$

Method: Least Squares

Date: 09/15/15 Time: 18:42

Sample: 2004Q1 2014Q4

Included observations: 44

\begin{tabular}{crrrr}
\hline \hline Variable & Coefficient & Std. Error & t-Statistic & Prob. \\
\hline \hline C & 186.4627 & 210.0954 & 0.887515 & 0.3810 \\
X1 & -10.82817 & 4.770643 & -2.269751 & 0.0297 \\
X2 & 0.051025 & 0.033690 & 1.514534 & 0.1391 \\
X3 & 2.586616 & 2.849550 & 0.907728 & 0.3704 \\
X4 & -1.535871 & 8.478676 & -0.181145 & 0.8573 \\
X5 & -0.822830 & 0.359113 & -2.291285 & 0.0283 \\
X6 & -0.894392 & 1.620149 & -0.552043 & 0.5845 \\
X7 & 0.095620 & 0.355219 & 0.269186 & 0.7894 \\
X8 & -448.8318 & 156.2998 & -2.871608 & 0.0070
\end{tabular}


INTERNATIONAL JOURNAL OF ACADEMIC RESEARCH IN BUSINESS AND SOCIAL SCIENCES

Vol. 8, No. 11, Nov, 2018, E-ISSN: 2222-6990 @ 2018 HRMARS

\begin{tabular}{lrlll}
\multicolumn{1}{c}{ X9 } & -0.004388 & 0.011273 & -0.389245 & 0.6995 \\
\hline \hline R-squared & 0.595238 & Mean dependent var & 14.00455 \\
Adjusted R-squared & 0.488095 & S.D. dependent var & 0.735206 \\
S.E. of regression & 0.526022 & Akaike info criterion & 1.749768 \\
Sum squared resid & 9.407762 & Schwarz criterion & 2.155266 \\
Log likelihood & -28.49490 & Hannan-Quinn criter. & 1.900146 \\
F-statistic & 5.555548 & Durbin-Watson stat & 0.745940 \\
Prob(F-statistic) & 0.000105 & & \\
\hline \hline
\end{tabular}

Source: processed researchers

The result of regression equation test is as follows:

$Y=186,4627-10,82817 X_{1}+0,051025 X_{2}+2,586616 X_{3}-1,535871 X_{4}-0,822830 X_{5}-0,894392 X_{6}+$ $0,095620 X_{7}-448,8318 X_{8}-0,004388 X_{9}+e$

From the above equation models, it can be concluded that the results show a negative correlation between GDP, Population, Poverty rate, Human Development Index, Productivity, and Minimum Wage to the Happiness Index, where are significant for GDP, Poverty, and Productivity. Meanwhile, Inflation, Money Supply, and Labor have a positive relationship to the Happiness Index but insignificant.

\section{DISCUSSION}

\section{A. Adjusted Coefficient Determination}

The result of model estimation with OLS method in table 2 shows that the adjusted coefficient determination $\left(\mathrm{AdjR}^{2}\right.$ ) of 0.48 . It means that $48 \%$ of Happiness Index changes are influenced by the determinant variables in this model (GDP, inflation, money supply, population, poverty rate, human development index, labor, minimum wage and productivity). While 52\% are explained by other variables those are not included in this model.

\section{B. T-Statistic Test Results}

\section{The Effect of GDP on economic development toward Happiness}

Base on the results in Table 2., it can be explained that the GDP variable obtains a beta value of 10.82817 and value of probability $<0.05$. The result indicates GDP negatively and significant affects the happiness index. This result explains that the higher level of economic growth will be the lower the happiness index, this condition is because the increase of GDP/economic growth rate is not accompanied by equal distribution of income so that only a small part of Indonesian people feel the impact of economic growth.

2. The Effect of Inflation on economic development toward Happiness

Inflation variable obtained a beta value of 0.051025 and value of probability $>0.05$. The results show that Inflation has a positive effect on happiness index but insignificant.

3. The Effect of Money Supply on economic development toward Happiness 
INTERNATIONAL JOURNAL OF ACADEMIC RESEARCH IN BUSINESS AND SOCIAL SCIENCES Vol. 8, No. 11, Nov, 2018, E-ISSN: 2222-6990 C 2018 HRMARS

Money supply variable has the beta value of 2.586616 and value of probability $>0.05$. The results show that money supply has a positive effect on the happiness index but insignificant. This result explains that economic growth or growth in the production of goods and services requires the availability of sufficient money, in order to increase corporate and community revenues, which in turn increases the index of happiness.

4. The Effect of Population on economic development toward Happiness

Population variable has a beta value of -1.535871 and value of probability $>0.05 t$. The result indicates that population has a negative effect but insignificant on the happiness index. This result explains that the higher the population growth the lower the happiness of the community.

5. The Effect of Poverty on economic development toward Happiness

Poverty level variable obtained a beta value of -0.822830 and value of probability $<0.05$. The results show that poverty negatively and significant affects the happiness index. This result explains that the more poor people will lower the happiness index.

6. The Effect of Human Development Index on economic development toward Happiness

Human development index (HDI) level variable obtains a beta value of -0.894392 and value of probability $>0.05$. The result indicates that the human development index has a negative effect but insignificant on the happiness index.

7. The Effect of Labor Force on economic development toward Happiness

Labor variable obtained a beta value of 0.095620 and value of probability $>0.05$. The results show that labor has a positive effect on the happiness index but insignificant.

8. The Effect of Productivity on economic development toward Happiness

Productivity variable obtained the beta value of $-448,831$ and value of probability , 0.05 . The results show that productivity has a negative and significant affect on the happiness index.

9. The Effect of Minimum Wage on economic development toward Happiness

Minimum wage variable obtains a beta value of -0.004388 and value of probability $>0.05$. The result shows that the minimum wage negatively but insignificant affects the happiness index.

\section{Sharia Model Test Result}

If in the previous section has been discussed the results of hypothesis testing with conventional regression model, then the next step is to examine regression model with sharia concept.

Table 3.

Model Estimation Result Using Theta

Dependent Variable: $Y$

Method: Least Squares

Date: 10/23/15Time: 14:28

Sample: 2004Q1 2014Q4

Included observations: 44 
INTERNATIONAL JOURNAL OF ACADEMIC RESEARCH IN BUSINESS AND SOCIAL SCIENCES Vol. 8, No. 11, Nov, 2018, E-ISSN: 2222-6990 @ 2018 HRMARS

Variable Coefficient Std. Error t-Statistic Prob.

\begin{tabular}{ccccc}
\hline \hline & & & & \\
C & -15.38752 & $1.17 \mathrm{E}-06$ & -13138404 & 0.0000 \\
X1 & $4.11 \mathrm{E}-07$ & $5.25 \mathrm{E}-13$ & 781716.4 & 0.0432 \\
X2 & 0.062805 & $8.43 \mathrm{E}-10$ & 74508405 & 0.1543 \\
X3 & $2.15 \mathrm{E}-07$ & $3.26 \mathrm{E}-14$ & 6584436. & 0.0000 \\
X4 & $2.99 \mathrm{E}-08$ & $1.86 \mathrm{E}-14$ & 1609664. & 0.0458 \\
X5 & 0.232198 & $8.55 \mathrm{E}-09$ & 27171378 & 0.0621 \\
X6 & 0.496963 & $3.68 \mathrm{E}-08$ & 13487914 & 0.0000 \\
X7 & 0.167348 & $8.70 \mathrm{E}-09$ & 19245338 & 0.0023 \\
X8 & 26.94611 & $2.76 \mathrm{E}-06$ & 9757761. & 0.0000 \\
X9 & 0.002874 & $3.14 \mathrm{E}-10$ & 9164171. & 0.0346 \\
X10 & $2.33 \mathrm{E}-08$ & $2.19 \mathrm{E}-14$ & 1064161. & 0.0287 \\
& & & & \\
\hline \hline R-squared & 0.705589 & Mean dependent var & 4.531456 \\
Adjusted R- & & & & \\
squared & 0.567855 & S.D. dependent var & 2.735127 \\
S.E. of regression & 0.826432 & Akaike info criterion & 1.749694 \\
Sum squared & & & & \\
esid & 6.707656 & Schwarz criterion & 2.155266 \\
Log likelihood & 28.49490 & Hannan-Quinn criter. & 12.00109 \\
F-statistic & 3.785520 & Durbin-Watson stat & 2.148940 \\
Prob(F-statistic) & 0.002105 & & \\
& & &
\end{tabular}

Source: processed

researchers

The partial test result (t-test) with the above sharia model shows that all variables (except Inflation and human development index) have probability values of $0.000<0.05$. Thus, it can be concluded that GDP, Money Supply, Population, Poverty Level, Labor Force, Productivity, and Minimum Wage have a significant effect on happiness. Meanwhile, the simultaneous test results ( $F$ test) shows a probability value of $0.000<0.05$, thus it can be concluded that simultaneously GDP, Inflation, Money Supply, Population, Poverty Rate, HDI, Labor Force, Productivity, and Minimum Wage have a significant effect on happiness. When compare to conventional test (where only GDP, Poverty and Productivity, significantly affect to Happiness Index), for sharia compliance test, only Inflation and Human Development Index have no significant effect on Happiness Index.

\section{CONCLUSION}

Based on the results of testing and analysis and discussion as has been done, and from the results of the hypothesis, it can be made several conclusions as follows: (i). From the conventional model, the 
INTERNATIONAL JOURNAL OF ACADEMIC RESEARCH IN BUSINESS AND SOCIAL SCIENCES Vol. 8, No. 11, Nov, 2018, E-ISSN: 2222-6990 @ 2018 HRMARS

results show a negative correlation between GDP, Population, Poverty rate, Human Development Index, Productivity, and Minimum Wage to the Happiness Index, where are significant for GDP, Poverty, and Productivity. Meanwhile, Inflation, Money Supply, and Labor have a positive relationship to the Happiness Index but insignificant; (ii). From the sharia model, all variables (except Inflation and human development index) have a positive and significant effect on happiness; (iii). Even though, these two model have the same significant results for the simultaneous test, but the sharia model has bigger adjusted $\mathrm{R}^{2}$ (56\% compare then $48 \%$ ); and (iv). Finally, to achieve Indonesian Society Happiness, we are should implemented the sharia compliance for every kinds of activity. Through sharia compliance, every human kind always remember that Allah will give them ease, blessing and keep away from greedy.

\section{Corresponding Author}

Prof.H.Muhammad Zilal Hamzah

Sekolah Tinggi Ilmu Ekonomi Bisnis Indonesia, Jakarta, Indonesia

Email: mz.hamzah@stiebi.ac.id

Address: Jalan Raya Kebayoran Lama No.46, Jakarta Barat, Indonesia, 11560.

\section{References}

Al-Quran and Hadist

Adam, R. H. and Jane, J. H., 1995. Sources Of Income Inequality And Poverty In Rural Pakistan. International Food Policy Research Institute Research Report 102, International Food Policy Research Institute. Washington DC.Munich Personal RePEc Archive (ARPA), Online at http://mpra.ub.uni-muenchen.de/41185/MPRA Paper No. 41185, posted 11. September 2012 11:24 UTC.

Anand, S. and Ravallion, M., 1993. Human Development in Poor Countries: On the Role of Private Incomes and Public Services, Journal of Economic Perspectives, 7(1): 133-150.

Antony, G. and Laxmaijah, A., 2008. Human Development, Poverty, Health and Nutrition in India. Indian Journal of Medical Research, 128: 198-205.

Anwar, S. and Watanabe, K., 2010. Predicting Future Depositor's Rate of Return Applying Neural Network: A Case-study of Indonesian Islamic Bank. Journal of Economics and Finance. 2(3).

Barro, R.J. and Sala-Martin, Xavier., 2004. Economic Growth. McGraw Hill. New York.

Chapra, U., 2008. The Future of Islamic Economic; An Islamic Prespective. Penerbit SEBI (edisi terjemah). Jakarta.

Choudhury, M. A., 2004. The Islamic World System. London and New York, Rouledge Curzon.

Costantini, V. and Monni, S., 2005. Sustainable Human Development for European Countries, Journal of Human Development, Vol. 6, No. 3, November 2005.

Fisher, I., 1991. The Purchasing Power Of Money, The Macmillan Company, New York.

Gujarati, D. N., and Porter, D. C., 2004. Basic Econometrics. McGraw Hill/Irwin Publishing. New York.

Halim, A. and Damayanti, T., 2007. Pengelolaan Keuangan Daerah Edisi: Kedua. Cetakan: Pertama. Penerbit UPP STIM YKPN, Yogyakarta.

Hamzah, M.Z., 2011. The Introduction of Fiscal Decentralization. Third Edition. LPS Sekolah IImu Ekonomi Bisnis Indonesia. Jakarta. 
INTERNATIONAL JOURNAL OF ACADEMIC RESEARCH IN BUSINESS AND SOCIAL SCIENCES

Vol. 8, No. 11, Nov, 2018, E-ISSN: 2222-6990 C 2018 HRMARS

http.undp.org/en/humandev/2011.

Irawan, M.I., 2009. Analisis Faktor-Faktor Yang Mempengaruhi Indeks Pembangunan Manusia (IPM) Di Indonesia, Thesis Fakultas Ekonomi. Universitas Sumatera Utara.

Ismail, A.G. and Haron, N., 2014. Happiness in Economics as Understood Across Islam and Religion. DOI: 10.1177/2158244014560543, Published 16 December 2014.

Joseph, D.R., 2005. The Dynamic Mass Communiaction: Media In The Digital Age 7th Edition.The Mc Graw-Hill Companies, New York.

Kayed, R.N. and Hassan, M.K., 2010. Islamic Entrepreneurship: A Case Saudi Arabia, penelitian diterbitkan di Journal of Developmental Entrepreneurship, vol.15, no.4, 2010.

Keynes, J. M., 1937. The General Theory of Employment Interest and Money. Brace and World, Harcourt.

Keysar, A. and Kosmin, A.B., 2008. International Survey Worldviews and Opinions of Scientist, India 2007-2008. Institute fo the Study Secularism. India.

Mankiw, N.G., 2006. Pengantar Ekonomi Makro, Edisi Ketiga. Penerbit Salemba Empat. Jakarta.

Poddar, A., Donthu, N. and Wei, Y., 2008. Website Costumer Orientation Website Quality and Purchase Intention The Role of Website Personality. Journal of Business Research 62 (2009) 441-450.

Salim, A., 2010. Mereduksi Kemiskinan; Sebuah Proposal Baru Untuk Indonesia. Nala Cipta Litera, Yogyakarta.

Todaro, M.P. and Smith, S.C., 2004. Pembangunan Ekonomi di Dunia Ketiga. Penerbit Erlangga, Jakarta.

Xiaoyan, W. and Liming, C., 2008. Study on the Evaluation of Regional Sustainable Development Based on Human Development Index, China. 